\title{
Congenital hypothyroidism due to transplacental passage of TSH-binding inhibitory antibodies
}

INSERM

\section{Source}

INSERM. (1999). Orphanet: an online rare disease and orphan drug data base. Congenital hypothyroidism due to transplacental passage of TSH-binding inhibitory antibodies. ORPHA:95715

Cong enital hypothyroidism due to transplacental passage of maternal thyroidstimulating hormone (TSH)-binding inhibitory antibodies is a type of transient congenital hypothyroidism (see this term), a thyroid hormone deficiency that is not permanent. 